Огляди літератури, оригінальні дослідження, погляд на проблему

УДК 616-002.44:616.14-007.64-08

DOI

\title{
ДЕЯКІ ПІДХОДИ ДО СУЧАСНОГО ЛІКУВАННЯ ХВОРИХ ІЗ ТРОФІЧНИМИ ВИРАЗКАМИ ПРИ ПІСЛЯТРОМБОФЛЕБІТИЧНОМУ СИНДРОМІ
}

\section{ДВНЗ «Тернопільський державний медичний університет імені І. Я. Горбачевського МОЗ України»}

РЕЗЮМЕ. Розглянуто новий погляд на комплексний підхід до лікування хворих із трофічними виразками при післятромбофлебітичному синдромі через вплив на основні патогенетичні механізми за допомогою комбінованої терапії з метою покращення ефективності загоєння ран.

КЛЮчОВІ СЛОВА: післятромбофлебітичний синдром, трофічна виразка, кверцетин, аргінін.

Трофічні виразки на фоні післятромбофлебітичного синдрому (ПТФС) $\epsilon$ актуальною медикосоціальною проблемою сучасного лікаря, оскільки значно обмежують працездатність таких хворих, тривалість перебування на стаціонарному та амбулаторному лікуванні $\epsilon$ значним, а часті рецидиви ведуть до інвалідизації [10]. ПТФС-хронічна венозна патологія, що обумовлена перенесеним гострим тромбозом глибоких вен. Частота цього ускладнення, за даними різних авторів, коливається від 5 до $10 \%$ хворих, причому у половини пацієнтів захворювання розвивається у перші 1-2 роки після гострого тромбозу глибоких вен, 3 них 25 \% потребують госпіталізації [13].

Клінічний перебіг ПТФС, як правило, характеризується відчуттям тяжкості та болями в ушкодженій кінцівці, що підсилюються під час ходьби, тривалого перебування на ногах, а також набряком тканин нижніх кінцівок й індурацією тканин у нижній третині гомілки, що обумовлено розвитком фіброзу й декомпенсацією регіонарної гемодинаміки, тривалим свербінням шкірних покривів. У 65-75 \% хворих внаслідок ПТФС розвивається вторинний варикоз, який поширюється на басейн великої і малої підшкірних вен $[10,14]$. Виразкування при ПТФС $\epsilon$ тяжким ускладненням через резистентність до лікування, тривалий період загоєння та ризик інфікування ранової поверхні. Описано чотири клінічні форми ПТФС: набряковобольова, варикозна, виразкова і змішана. За ступенем гемодинамічних порушень розрізняють субкомпенсацію та декомпенсацію, а за стадіями тромбозу - оклюзію глибоких вен і реканалізацію глибоких вен[6].

Проте проблема трофічних виразок при ПТФС має розцінюватися спеціалістом не тільки як локалізоване хронічне запалення та виразкування з можливим інфікуванням м'яких тканин на тлі порушення місцевого кровообігу, крово-та лімфовідтоку, але й як системна реакція організму, яка проявляється дискоординованою роботою систем перекисного окиснення ліпідів (ПОЛ) та антиоксидантної системи захисту (АОСЗ), цитокінового статусу, метаболічного гомеостазу. Підтвердженням впливу системних механізмів на прогресування виразкування та збільшення тривалості загоєння уже існуючих ран при варикозній хворобі $\epsilon$ часті коморбідні стани у таких хворих (ожиріння, цукровий діабет, гіпертонічна хвороба, серцево-судинна недостатність, атеросклероз та ін.). Тому метою лікування таких пацієнтів $\epsilon$ вплив на основні патогенетичні механізми розвитку ускладнень при ПТФС: стимулювання репаративних властивостей в місці ураження та вплив на різні регуляторні системи організму. Монооксид азоту (NO) - яскравий та потужний модератор багатьох фізіологічних функцій та патофізіологічних процесів, відомо, що його дефіцит або гіперпродукція має як про-, так і протизапальні властивості. При хронічних захворюваннях дефіцит NO може сприяти вільнорадикальному окисненню ліпідів та зменшенню резервних можливостей системи антиоксидантного захисту. Донатор оксиду азоту - L-аргінін (а-аміно- $\delta$-гуанідиновалеріанова кислота) - поєднує властивості, які можуть впливати на багато ланок патогензу при трофічних виразках на тлі посттромбофлебітичного синдрому. Основний метаболіт аргініну NO має цитопротекторну дію, його дефіцит веде до активації процесів вільнорадикального пошкодження мембран клітин. Зокрема, прозапальна та протизапальна дія залежить від багатьох факторів та їх поєднання характеру перебігу захворювання, його тяжкості, ступеня активності індуцибельної продукції NO (утворення високих концентрацій NO, що індукується тригерними факторами - цитокінами), стану місцевих окиснювально-відновних механізмів. Відмічено, що з віком активність NOS знижується, відповідно в пацієнтів більше 75 років рівень NO в крові в 3-4 рази нижчий, ніж у 25-30-річних пацієнтів [4]. NO обмежує деструктивний вплив стресреакцій шляхом прямого зменшення стресорної активації вільнорадикального окиснення ліпідів (ВРОЛ) через підвищення активності антиокси- 
Огляди літератури, оригінальні дослідення, погляд на проблему

дантних ферментів і через пригнічення синтезу асиметричного диметиларгініну, а недостатній синтез NO призводить до ушкодження мембран клітин продуктами вільнорадикального окиснення. В умовах зниженого синтезу NO захисні механізми не функціонують, отже, запускаються механізми запалення [1]. Сам NO має антиоксидантні властивості $[3,11]$. Аргінін бере участь у підтриманні білкового балансу, в процесі синтезу білка, та $\epsilon$ необхідним для цитоплазмового ядерного біосинтезу у всіх тканинах, активно спряє накопиченню клітинної енергії. Ці властивості роблять аргінін важливим для росту, регенерації тканин, відновлення функцій після різних травм чи захворювань.

Отже, аргінін має антигіпоксійну, мембраностабілізувальну, цитопротекторну, антиоксидантну, дезінтоксикаційну, гепатопротекторну дію. Багатогранність ефектів L-аргініну, як донатора оксиду азоту в організмі, робить його актуальним об'єктом для вивчення й у плані ефективності використання в лікуванні хворих на ПТФС, причому даних про застосування засобу при даній патології в літературі зустрічається мало.

В багатьох програмах комплексного лікування ПТФС із трофічними виразками застосовують флавоноїди (аналоги вітаміну Р), через їх високу ангіопротекторну дію. Кверцетин (2-(3,4-дигідроксифеніл)-3,5,7-тригідрокси-4Н-1бензопіран-4-он дигідрат) - флавоноїд, $\epsilon$ агліконом багатьох рослинних флавоноїдних глікозидів, у тому числі рутину, і належить до вітамінних препаратів групи Р. Описані дані щодо протизапального ефекту кверцетину, завдяки блокаді ліпооксигеназного шляху метаболізму арахідонової кислоти, зниженню синтезу лейкотрієнів, серотоніну та інших медіаторів запалення, підсилює дію нестероїдних протизапальних препаратів. Репаративні властивості кверцетину досліджені також, вони полягають у прискоренні загоєння ран. Препарат може впливати на процеси ремоделювання кісткової тканини, він проявляє стійку імуномодулювальну активність. Експериментально визначені також діуретичні, спазмолітичні, антисклеротичні властивості. Використання кварцетину має вазидилатуючу дію - блокує надходження кальцію в гладком'язові клітини судинної стінки, що запобігає вазоконстрикції. Інактивує фермент аденозиндезаміназу, що веде до вазодилатації та підсилює синтез оксиду азоту ендотелієм, який, як відомо, $\epsilon$ потужним вазорелаксуючим медіатором. Кверцетин знижує проникність судинної стінки, в'язкість крові, здатність еритроцитів та тромбоцитів до агрегації, покращує мікроциркуляцію $[8,9,12,15]$. Доведені імуномоделюючі властивості кверцетину через підвищення неспецифічної резистентності організму шляхом зростання фагоцитарної активності макрофагів [2]. $€$ також повідомлення щодо застосування препарату в кардіології (ішемічна хвороба серця, нейроциркуляторна дистонія), неврології (ішемічний інсульт, клімактеричний, вертебральнобольовий синдром, нейрорефлекторні прояви остеохондрозу хребта), хірургії (гнійно-запальні захворювання м'яких тканин, мікро-, макроангіопатії, місцеві променеві ураження після рентген- і гамма-променевої терапії, для їх профілактики), стоматології (пародонтити, ерозивно-виразкові ураження СО ротової порожнини) [5]. Тобто, результати досліджень переконують, що курс лікування кверцетином сприятиме істотному покращенню антиоксидантного гомеостазу, процесів мікроциркуляції, кисневого забезпечення та репаративної здатності усіх тканин.

Таким чином, найбільш вираженими ефектами кверцетину, які необхідні для лікування хворих із трофічними виразками при ПТФС, є: антиоксидантний, мембраностабілізуючий, протизапальний, спазмолітичний, імуномоделюючий та анаболічний $[8,9]$.

Не дивлячись на удосконалення методик лікування, впровадження в практику нових поколінь препатарів, проблеми в лікуванні хворих з трофічними виразками при ПТФС залишаються невирішеними. Тому, окрім традиційного лікування трофічних виразок при ПТФС, яке включає еластичне бинтування, антикоагулянтну терапію, антибіотики, протеолітичні ферменти, десенсибілізувальні засоби, сечогінні препарати тощо $[7,14]$, доцільним було 6 дослідити ефективність застосування комплексу аргініну та кверцетину з метою покращення очищення та загоєння ран, зменшення вираженості симптоматики, що привело 6 до зниження тривалості непрацездатності у таких хворих.

\section{ЛІТЕРАТУРА}

1. Аргинин в медицинской практике / Ю. М. Степанов, И. Н. Кононов, А. И. Журбина, А. Ю. Филиппова // Сучасна гастроентерологія. - 2005. - № 4 (24). - С. 121-127.

2. Бутов Д.О. Ефективність комплексного лікування хворих на вперше діагностований деструктивний ту- беркульоз легень із використанням кверцетину з полівінілпіролідоном : автореф. дис. на здобуття наукового ступеня канд. мед. наук : 14.01.26 / Д.О. Бутов // Нац. ін-т фтизіатрії і пульмонології ім. Ф.Г. Яновського АМН України. - К., 2010. -20 c. 
Огляди літератури, оригінальні дослідження, погляд на проблему

3. Ванин А. Ф. Оксид азота регулятор клеточного метаболизма / А. Ф. Ванин // Соросовский образовательный журнал. - 2001. - Т. 7, №11. - С. 7-12.

4. Ивашкин В. Т. Оксид азота в регуляции функциональной активности физиологических систем / В. Т. Ивашкин, О. М. Драпкина // Росс. журн. гастроэнтерол., гепатол. и колопроктол. - 2000. - № 4. - С. 16-21.

5. Максимів О. О. Ефективність застосування кверцетину як терапії супроводу при протезуванні повними знімними протезами у хворих на цукровий діабет 2-го типу / О. О. Максимів // Буковинський медичний вісник. - 2014. - T. 18, № 4 (72). - С. 73-77.

6. Post-thrombotic syndrome: a clinical review / Baldwin M. J., Moore H. M., Rudarakanchana N. [et al.] // J. Thromb. Haemost.- 2013. - № 11. - P. 795.

7. Relation between quality of anticoagulant treatment and the development of the postthrombotic syndrome/ Dongen C. J., Prandoni P., Frulla M. [et al.] // J. Thromb. Haemost. - 2005. - № 3. - P. 939-42.

8. Effect of the flavonoid quercetin on inflammation and lipid peroxidation induced by Helicobacter pylori in gastric mucosa of guinea pig / R. González-Segovia, J. L. Quintanar, E. Salinas [et al.] // J. Gastroenterol. 2008. - Vol. 43. - P. 441-447.

9. Flavonoid intake and coronary mortality in Fin- land: a cohort study / P. Knekt, R. Jarvinen, A. Reunanen, J. Maatela // BMJ. - 1996. - Vol. 312. - P. 478-481.

10. Prevention and treatment of postphlebitic syndrome: results of a 3-part study /J. Ginsberg, J. Hirsh, J. Julian [et al.] //Arch. Intern. Med. - 2001. - № 161. - P. 2105-2109.

11. Immune and metabolic effects of arginine in the surgical patient / J. M. Daly, J. Reynolds, A. Thorn [et al.] // Ann. Surgery.-1988.- Vol. 206, № 4. - P. 512-523.

12. Ingestion of quercetin inhibits platelet aggregation and essential components of the collagen-stimulated plateletactivation pathway in humans / G. P. Hubbard, S. Wolffram, J. A. Lovegrove, J. M. Gibbins // J. Thromb. Haemost. - 2004. - Vol. 2. - P. 2138-2145.

13. Definition of post-thrombotic syndrome of the leg for use in clinical investigations: a recommendation for standardization / Kahn S. R., Partsch H., Vedantham S. [et al.] // J ThrombHaemost. - 2009. - № 7. - P. 879.

14. Neglen P. Invasive treatment of post-thrombotic syndrome // P. Neglen // Phlebolymphology. - 2006. № 13. - P. 163-171.

15. Quercetin inhibits lymphocyte activation and proliferation without inducing apoptosis in peripheral mononuclear cells / E. Lugli, R. Ferraresi, E. Roat [et al.] // Leukemia Research. - 2009. - Vol. 33. - P. 140-150.

\section{SOME CURRENT APPROACHES TO THE TREATMENT OF PATIENTS WITH TROPHIC ULCERS IN POSTTHROMBOTIC SYNDROME}

@B. O. Mihenko

\section{SHEI «Ternopil State Medical University by I. Ya. Horbachevsky of MPH of Ukraine»}

SUMMARY. This article describes the new view of an integrated approach to the treatment of patients with trophic ulcers in post-thrombotic syndrome by influencing main pathogenic mechanismsus in combination therapy to improve the effectiveness of healing.

KEY WORDS: postthrombotic syndrome, venous ulcer, quercetin, arginine. 